$2 \sigma^{7} 1$ \& Stephansort, $1 \sigma^{7}$ Milne Bay, Br. N. Guinea. Length, $11 \mathrm{~mm}$.

Type: o Stephansort (coll. Bowditch).

Head faintly and sparingly punctulate with a dark median line, antennæ reaching the middle of the body the scape wholly and second joint partly flavous, thorax shining, impressed on either side of the disk, moderately and unevenly punctulate, obsolete at the sides, which are rounded and slightly reflexed, anterior angles rounded, posterior obtuse, scutel obtusely pointed behind, elytra shining, rather more strongly punctulate, near the base, punctures becoming obsolete and fine as they enter the black space, sutural margin thickened near the apex, entire underside dirty flavous; two of the specimens were in the $2 \mathrm{~d}$ Jacoby coll. under the name dimidiatum Blanch. but the size, shape and metasternal process separate it at once.

Oides femoratus sp. nov.

Smooth, convex, flavous, antennæ, most of the head, under side of the body largely and legs, except the basal two thirds of the femora black, scutellum and margin of the suture fuscous, $\sigma^{\top}$ with metasternum produced into a well marked obtuse process.

Type: $\sigma^{\text {T }}$ Cooktown (Austral.) (square dark blue paper label) 2 spec. (unnamed in $2 \mathrm{~d}$ Jacoby coll.) (coll. Bowditch). Length, $9 \mathrm{~mm}$.

Head with a few fine punctures and impressed line on the front like confusus (vide supra), mouth yellow, antennæ reaching the middle of body, the scape more or less rufous, thorax smooth, shining, faintly impressed on the disk, very faintly punctulate, anterior angles rounded, posterior obtuse, sides margined and faintly explanate, scutellum large very obtusely rounded at apex, elytra convex, everywhere faintly and evenly punctulate, the extreme sutural edge thickened, under side mostly shining black, with the pro and mesothorax somewhat flavous, and coxæ and trochanters more or less yellow, legs black except the basal two thirds of the femora; the color of the legs and the metosternal process (which is black) easily distinguish this form, the upper color makes the species resemble suturalis Jac. from New Guinea.

\title{
SOME COMMENTS ON THE VALUE OF WARNING COLORS AND MIMICRY IN INSECTS.
}

\author{
By C. H. Richardson,
} New Jersey Agricultural Experiment Station, New Brunswick, N. J.

During the course of an extended field trip through Nevada and eastern California several years ago, I had an opportunity to make some observations on the feeding habits of certain amphibians and reptiles. As several of these observations throw light upon the protective value of warning colors and mimicry in insects, they are given in the hope that they will be a real contribution, even though a meager one, to these disputed questions.

In the region about Pyramid Lake, Nev., the fleet-footed gridiron-tailed lizard (Callisaurus ventralis Hallowell) was very abun- 
dant. Examination of the stomach contents of a number of these lizards showed that their normal food was composed of various insects and bits of tender plant foliage. I was however, quite surprised to find in the stomach of one adult male, shot at Derby, Nev., two wasps so conspicuously banded as to place them unmistakably in the category of insects possessing warning colors. One had black and yellow bands on the thorax and abdomen, the other black and gray-white bands on the abdomen. Another wasp in a partially disintegrated condition, one insect larva, other insect fragments, a number of green leaves and a few pebbles furnished the bulk of the stomach ingredients. The whole mass of food had begun to decompose and the colors of the insects were considerably dimmed. It is evident here that a mature lizard (with full adult colors and testes enlarged) did not discriminate between conspicuously banded stinging insects and a harmless white larva. As further evidence that Callisaurus shows no aversion to bright colors, I may add that small, vivid purple flowers were found in the stomach of one individual. Merriam ${ }^{1}$ states that blossoms form a considerable part of the food of this species and although he does not give the colors of the blossoms, it is fair to assume that a comparatively large number are brilliantly colored, as brilliantly colored flowers grow abundantly throughout the habitat of Callisaurus.

At Tallac, Lake Tahoe, Cal., I watched a large adult leopard frog (Rana pipiens), on one occasion for a considerable length of time. I was concealed so that I could observe the actions of the frog, yet it could not see me. In the course of its wanderings over a grassy meadow, the frog captured an insect which was taken into its mouth, ejected, taken into its mouth again and finally discarded. The insect proved to be a drone fly, closely resembling certain species in the Syrphid genus, Eristalis. The first abdominal segment of the fly bore two conspicuous yellow triangularshaped markings, the apices of which did not quite meet mediodorsally. Here, then, we have a mimicking insect whose form and vivid color pattern combined were not of sufficient warning significance to ward off an insectivorous enemy. Just why the frog refused to eat the fly is not quite clear, possibly it was distasteful, but it is certain that the fly was mutilated beyond recovery.

${ }^{1}$ N. A. Fauna No. 7, 1893, p. 172. 

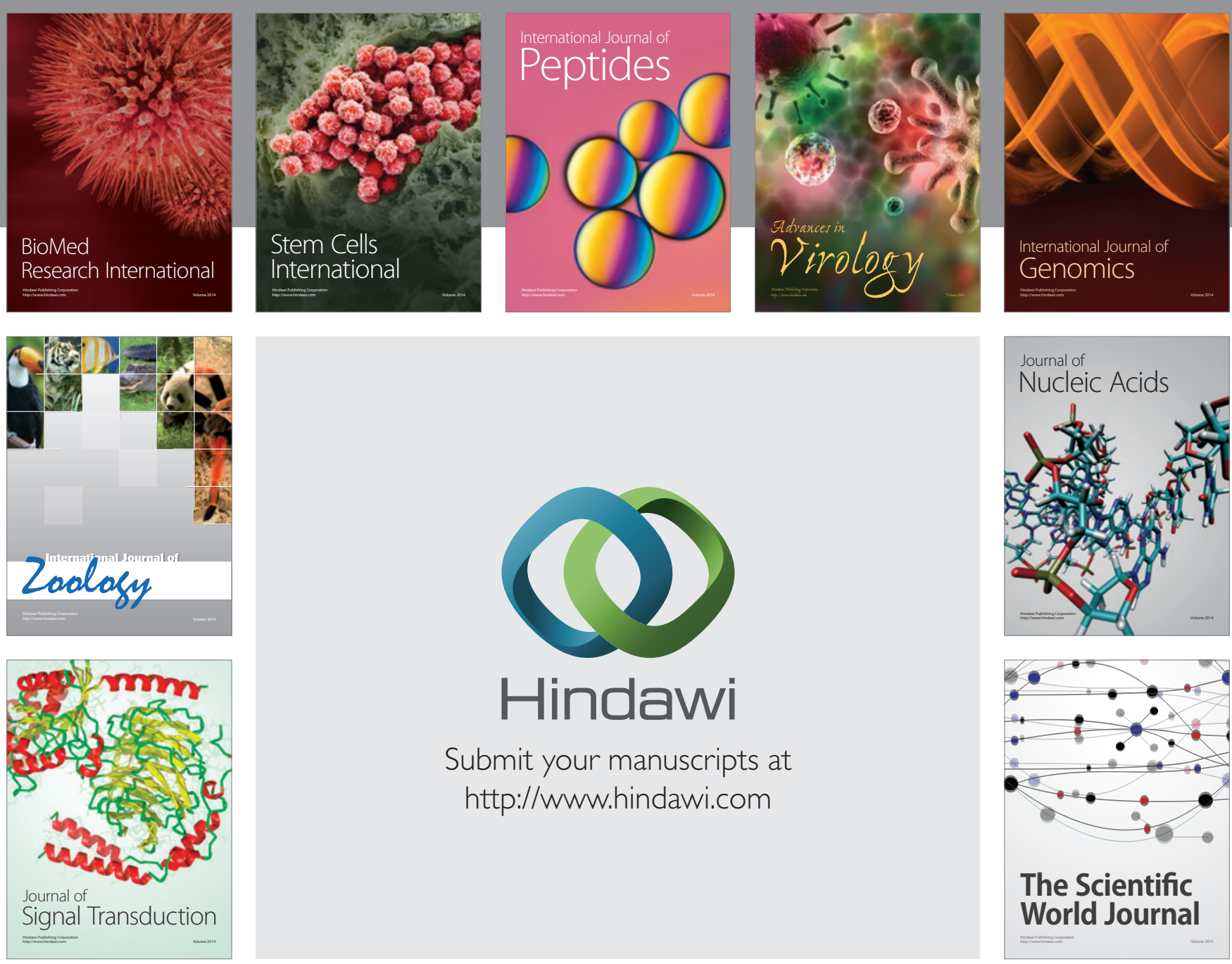

Submit your manuscripts at

http://www.hindawi.com
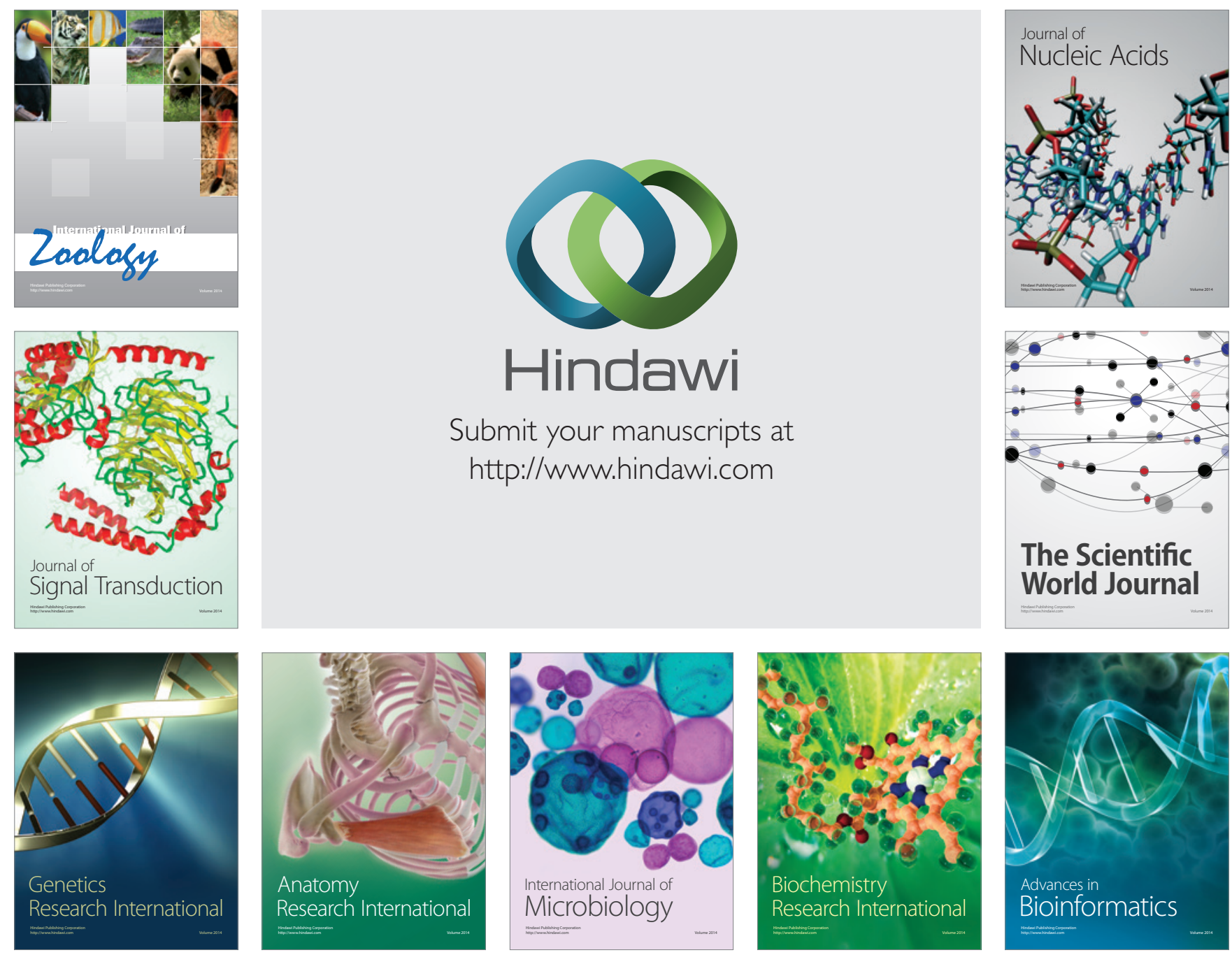

The Scientific World Journal
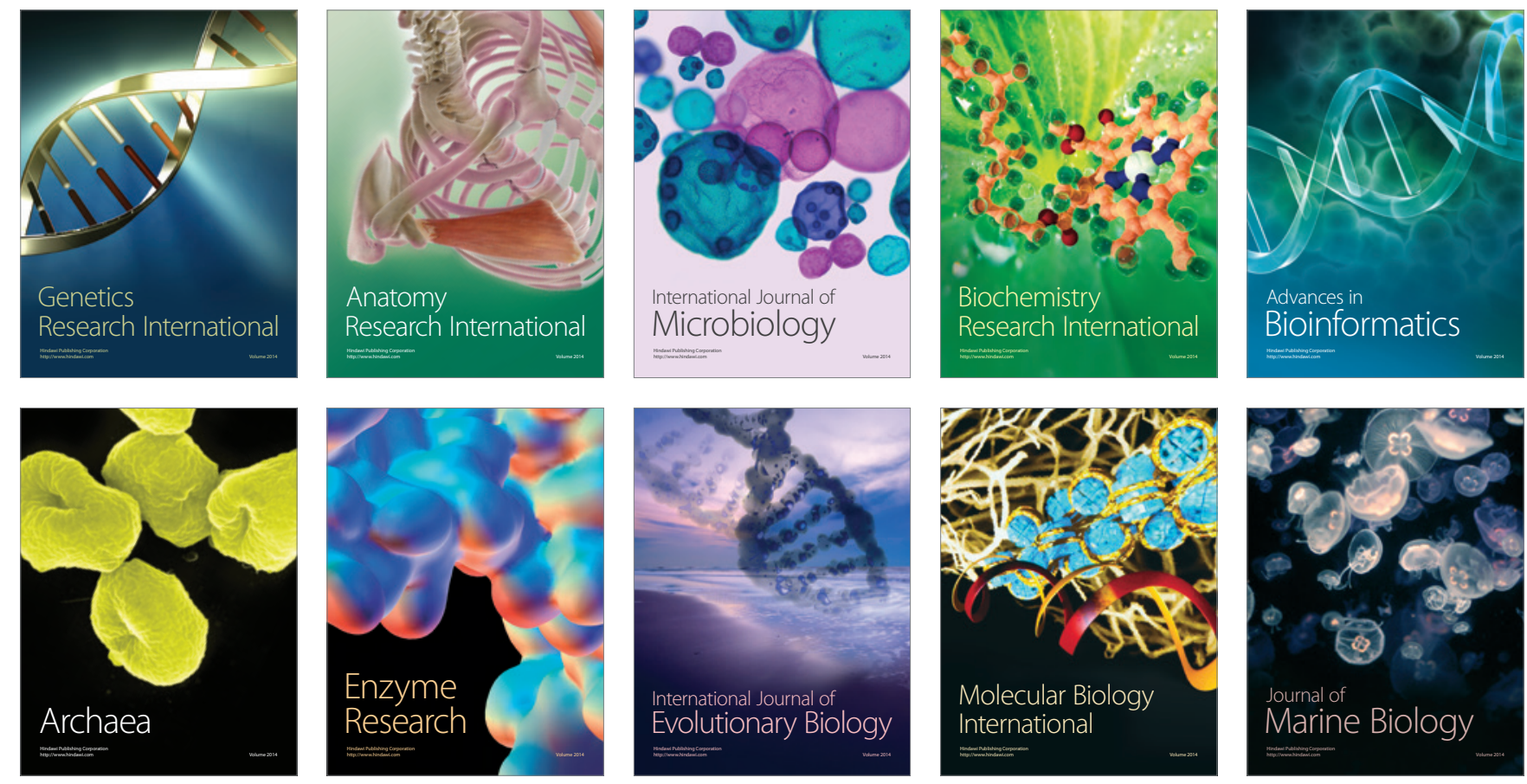